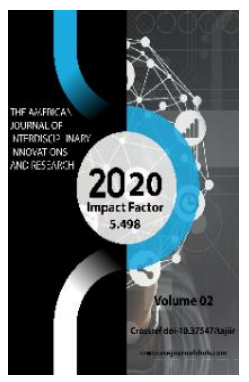

Journal Website: http://usajournalshub.c om/index,php/tajiir

Copyright: Original content from this work may be used under the terms of the creative commons attributes 4.0 licence.

\section{Role Of Exports Of Fruit And Vegetable Products In Ensuring The Sustainability Of Foreign Trade}

\author{
Kamoliddin Ikromiddinovich Sirojiddinov \\ Candidate Of Economic Sciences, Associate Professor, Department Of Economics, Namangan \\ State University, Uzbekistan
}

Abdulakhad Abdurashidovich Mirsoliev

Master Student, Department Of Economics, Namangan State University, Uzbekistan

\title{
ABSTRACT
}

The article considers and discusses the factors and opportunities for increasing the role of fruit and vegetable exports in ensuring the stability of foreign trade in Uzbekistan.

\section{KEYWORDS}

Agricultural sector, fruits and vegetables, agro-marketing research, Global GAP, export-import operation.

\section{INTRODUCTION}

Market changes in agriculture in Uzbekistan will lead to significant structural changes in the agricultural sector of the economy. The food industry is strengthening, there is a rapid growth in the production of fruits and vegetables. This is due to both the presence of favorable natural and climatic conditions, labor resources, national historical traditions, and the direction of material, technical and financial resources in agriculture, the transfer of agricultural production to a modern technology and technological basis, the introduction of technical and selection achievements.

The fruit and vegetable direction of agriculture in Uzbekistan has great opportunities for exporting its products and can take a worthy place in foreign trade and contribute to ensuring its sustainability. Accordingly, the study of the problems 
associated with the organization and expansion of exports of fruits and vegetables is of particular relevance and importance. With a general approach, state support for entrepreneurship, the provision of wide opportunities and benefits for producers, the consistent liberalization of export-import operations and currency relations have become an important factor in increasing the export potential of enterprises in all sectors of the economy, including those who produce fruit and vegetable products. Serious work is being done in the regions of the country to provide the population with quality food products, increase horticultural products, expand the area under vegetables and potatoes to create intensive early ripening and fertile gardens.

\section{THE MAIN FINDINGS AND RESULTS}

In recent years, more than 20 new highquality, high-yielding, disease-resistant varieties of fruits and grapes have been created in the country. A new method of growing fruit trees in special pots allows the development of horticulture on reclamation, saline and low-fertile lands. However, an increase in agricultural production by itself does not lead to an increase in product exports. In modern conditions, even for the domestic market, products should be manufactured taking into account the needs and preferences of potential consumers. In cases of export, it is necessary to clarify the main groups of consumers and the characteristics of the needs in the respective countries. Agromarketing research contributes to a more successful solution of such problems and allows you to respond in a timely manner to changes in the needs and demand of buyers at all stages of the movement of fruit and vegetable products from production to the final consumer.

In Uzbekistan, in recent years, there has been a noticeable increase in the export of fruits and vegetables (Figure 1).

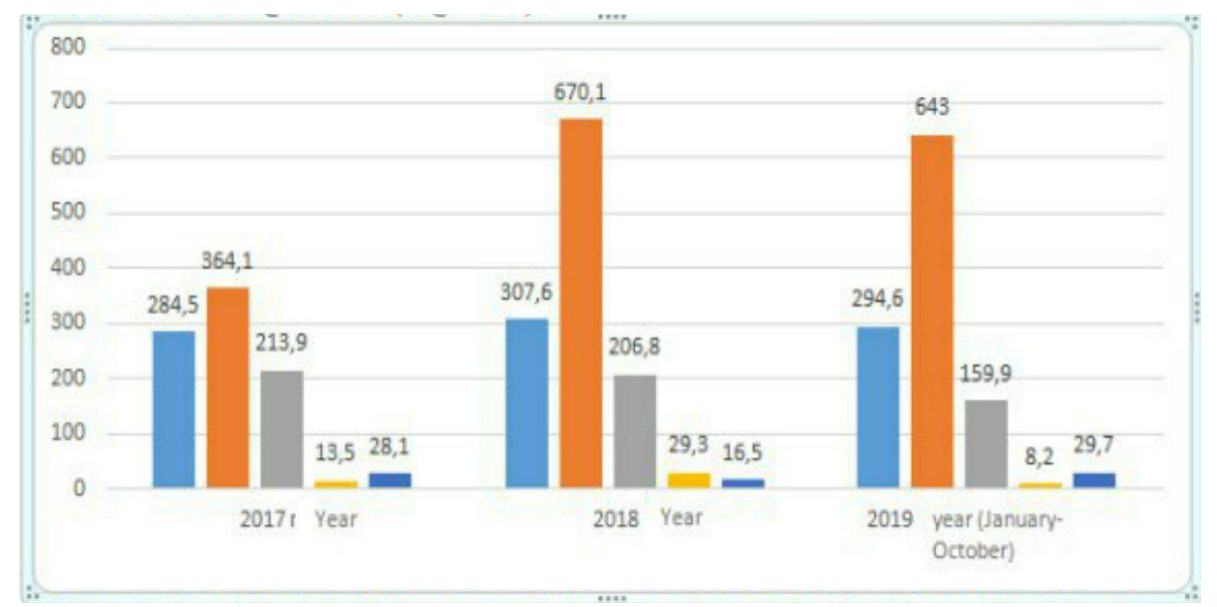

Figure 1. Dynamics of exports of fruits and vegetables (thousand tons)

According to Figure 1, it can be seen that in 2017 Uzbekistan exported 284.5 thousand tons of fruits, 364.1 thousand tons of vegetables, 213.5 thousand tons of grapes,
13.5 thousand tons of peanuts and 28.1 thousand tons of melons and watermelons. (Total 1004.1 thousand tons). In 208, these figures were, respectively, 307.6 thousand 
tons, 670.1 thousand tons, 206.8 thousand tons, 29.3 thousand tons and 165.5 thousand tons (Total 1230.3 thousand tons. ) for the nine months of 2019, the total volume of exports of fruits and vegetables amounted to 1,135.4 thousand tons, i.e. the trend towards accelerated growth in exports of products continued. Uzbekistan has great potential for a sharp increase in exports of fruits and vegetables, first of all, the specificity of the products grown here and the nutritional value of vitamins. One of the serious problems with exports is that the products offered do not meet the standards of developed countries.
The accelerated development of the market for fruits and vegetables has led to the fact that in the USA, the European Union and in many developed countries there is no demand for products that are not included in the category "Premium". In addition, each country has its own requirements for color, caliber, organoleptic properties, minimum amount and composition of chemical fertilizers. In 2020, Uzbekistan began extensive work on the introduction of 250 farms of the European Global GAP standard, which should open access for their products to the markets of European countries.

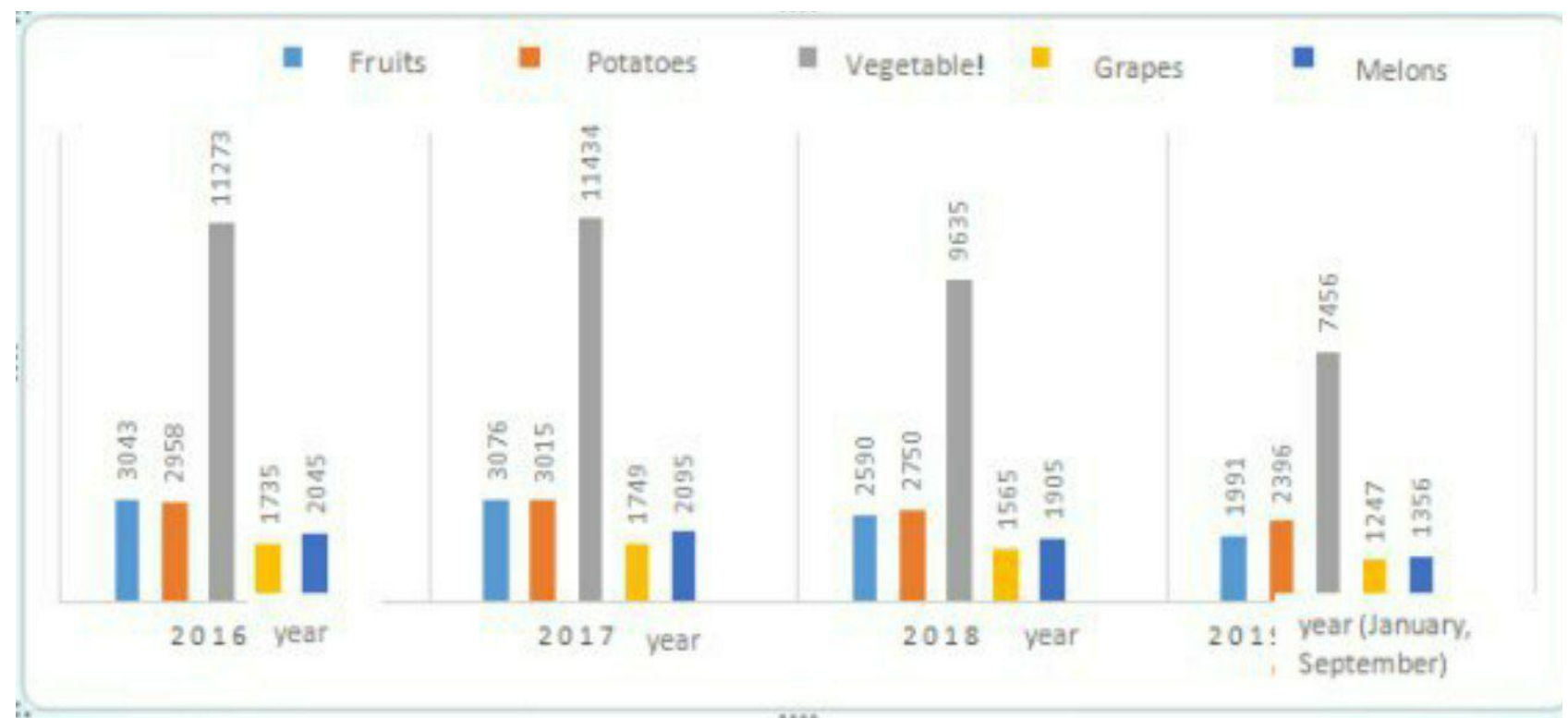

Figure 2. Volumes of production of fruits and vegetables (thousand tons)

Of course, every exporter should start their foreign trade activity by developing a marketing strategy that includes studying and understanding the specifics of the foreign market. That's what making effective and efficient marketing decisions is all about. As it is known, the President of the Republic of Uzbekistan has obligated all diplomatic missions of the country for the sake of foreign exporters in the study of relations with foreign partners. In the beginning of 2020, the government decided to compensate for the high expenditures of exporters on the transportation of goods by rail. Since May 2020, this procedure has been extended to the transportation of export goods by road 
and air, which greatly facilitates the export of fruit and vegetable products.

Currently, the world food market is growing demand not only for fresh fruits and vegetables, but also for deeply processed form. In almost all countries of the world, the share of fruits, vegetables and melons in the diet of the population is growing, which leads to a steady increase in demand for them. In such conditions, agricultural producers in Uzbekistan should fully use the opportunities to increase exports.

\section{CONCLUSION}

The coronavirus pandemic requires more effective and widespread measures to support the production and export of fruits and vegetables. Uzbekistan plans to double the production of fruits and vegetables by 2020, 55 regions specialize in the production of such products, 86 clusters and 125 cooperatives are being established. In 2020, 10.3 million tons of products will be directed to the consumption of the population, and 2.3 million tons will be exported, which means almost a doubling of the volume of exports, the Government intends to allocate $\$ 377.6$ million to the development of the fruit and vegetable industry in the regions in 2020 US foreign exchange funds. The financing of the industry is expanding through all channels. For example, in the Pap district, 25 billion soums are allocated for the repair of water pumping stations, and 800 wells will be drilled for irrigation in the Chust district.

Unfortunately, one of the factors limiting fruit and vegetable exports is the monopolization of fruit and vegetable exports. A limited number of business entities are licensed for this activity. This allows them to take full responsibility for the economic risks they face, which significantly reduces their financial and investment opportunities. In our opinion, the full functioning of fruit and vegetable clusters should allow to overcome this negative trend.

\section{REFERENCES}

1. "On the Strategy of Actions for the Further Development of the Republic of Uzbekistan". Decree of the President of the Republic of Uzbekistan, February 7, 2017. - The People's Word, 8 February 2017.

2. Decree of the President of the Republic of Uzbekistan "On measures to further ensure the food security of the country." http://www.lex.uz/ -

3. Sirojiddinov I.K, Botirova R. A. Opportunities for the development of exports of fruits and vegetables in the regions. Actual challenges of modern science.Collection of scientific papers. Issue 11 (31).Part I // PereyaslavKhmelnitsky, 2018. -pp. 82-85.

4. Sirojiddinov I.K, Botirova R.A. Opportunities for the development of export of fruits and vegetables in the Namangan region. Young scientist, No. 50, 2018. -pp. 174-176. 